\title{
PREDICTION OF CLEARNESS INDEX FOR SOME NIGERIAN STATIONS USING TEMPERATURE DATA
}

\author{
E.O. Falayi ${ }^{1}$ and A.B. Rabiu ${ }^{2}$ \\ ${ }^{1}$ University of Sussex, \\ Department of Space Centre, Falmer, Brighton, United Kingdom \\ ${ }^{2}$ Federal University of Technology, Department of Physics. Akure, Nigeria
}

\begin{abstract}
Global solar radiation and mean temperature data for five Nigeria stations have been used to fit the Angstrom model for the clearness index $\left(K_{T}=H / H o\right)$, the mean temperature $\left(T_{\text {mean }}\right)$ and maximum temperature $\left(T_{\max }\right)$. The tests of performance of the model for the five stations have been done in terms of the widely used statistical indicators, Mean Bias Error (MBE) and Root Mean Square Error (RMSE). It was found from statistical model performance indicators that the models provided reasonably high degree of precision in the prediction of average monthly global solar radiation on horizontal surfaces.
\end{abstract}

Keywords: Clearness index, Global solar radiation, and Temperature.

\section{INTRODUCTION}

Solar energy is an alternative energy source that can be used to supplement the convectional energy sources in tropical areas. The agriculturists, architects, hydrologists, climatologist, and ventilating engineers depend on availability of information on solar radiation. The technology development of solar energy must start with ensuring of accurate study of radiation data at different status. The global solar irradiance is affected by the atmospheric condition and meteorological parameters such as turbidity, relative humidity, degree of cloudiness, temperature and sunshine duration (Akinbode, 1992; Rietveld, 1978; Soler, 1979; Hargreves et al., 1985; De Jong and Stewart, 1993).
There had been investigation by Angstrom (1924), Arize and Obi (1983), Fagbenle (1990) on the ability of the Angstrom-page model to predict global solar radiation using the temperature and sunshine duration at different locations in Nigerian northern cities. A model was developed using temperature data by Hagreaves et al. (1985) to predict the global solar irradiance on horizontal surfaces in Nigeria environment.

The major aim of this paper is to determine the applicability of the Angstrom page regression model for estimating global solar irradiance from surface temperature which includes the maximum temperature and mean temperature data for five stations viz: Ikeja, Ibadan, Port Harcourt, Benin

94 Journal of Science and Technology, Vol. 28, No. 2, August, 2008 
and Ilorin. The performance of the model is also investigated using statistical indicators.

\section{MATERIALS AND METHODS}

The data set used which include mean hourly global solar radiation, maximum or minimum temperature, for a solar cycle (1980-1990) for five locations in Nigeria listed on Table 1 and displayed in figure 1 , were obtained from the Archives of Nigeria Meteorological Agency, Oshodi, Lagos State.

\section{Table 1:Geographical Location of the Station}

\begin{tabular}{ll}
\hline Stations & Locations \\
\hline Ikeja & $6.39^{0} \mathrm{~N} 3.23^{0} \mathrm{E}$ \\
Ilorin & $6.50^{0} \mathrm{~N} 4.56^{0} \mathrm{E}$ \\
Ibadan & $7.22^{0} \mathrm{~N} 3.58^{0} \mathrm{E}$ \\
Port Harcourt & $4.43^{0} \mathrm{~N} 7.05^{0} \mathrm{E}$ \\
Benin & $5.25^{0} \mathrm{~N} 5.30^{0} \mathrm{E}$ \\
\hline
\end{tabular}

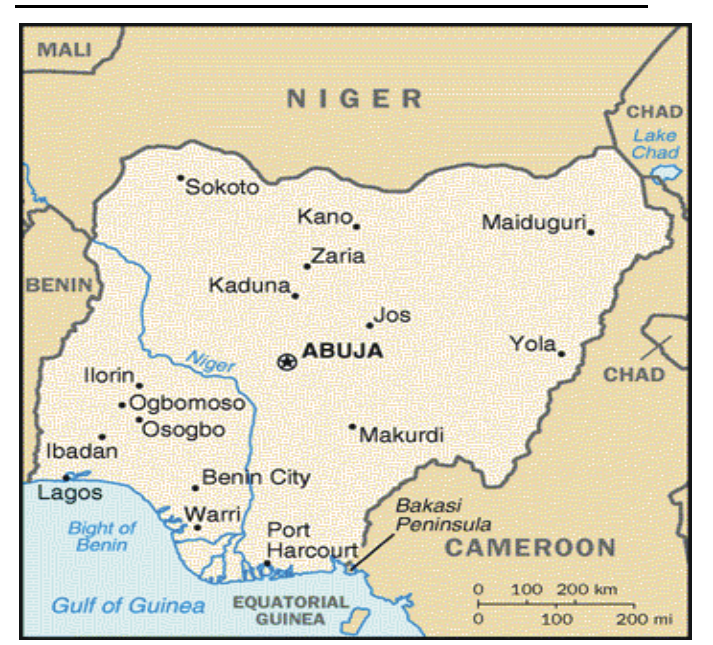

Fig 1: Map of Nigeria showing the stations

The hourly global solar radiation which were obtained using Gun - Bellani distillate were converted and standardized as used by Folayan (1988), using the conversion factor of (1.357士 0.176) $\mathrm{H}_{\mathrm{GB}} \quad \mathrm{MJ} / \mathrm{m}^{2}$

$$
\mathrm{H}_{\mathrm{gs}}=(1.35 \pm 0.176) \mathrm{H}_{\mathrm{GB}} \quad \mathrm{MJ} / \mathrm{m}^{2}
$$

Where $\mathrm{H}_{\mathrm{gs}}$ is the hourly global solar radiation in $\mathrm{MJ} / \mathrm{m}^{2}, \mathrm{H}_{\mathrm{GB}}$ is the raw data obtained using Gun-Bellani distillate.

Angstrom (1924) and Page (1964) used an expression in the linear regression model to correlate the measured global solar radiation data $(\mathrm{H})$ with surface temperature $\left(\mathrm{T}_{\mathrm{s}}\right)$ given by:

$$
H=H_{0}\left[a+b\left(T_{s}\right)\right]
$$

where $\mathrm{H}$ is the monthly mean horizontal daily total terrestrial solar radiation. Ho is the monthly mean horizontal daily total extraterrestrial solar radiation $\mathrm{a}$ and $\mathrm{b}$ are climatic constants;

$\mathrm{T}_{\mathrm{S}}$ is the corresponding value of mean temperature and maximum temperature

The mean monthly extraterrestrial radiation $\mathrm{H}_{-}$ on the horizontal surface for a period of one day is given by the expression.

$H_{0}=\frac{243600}{\pi} \operatorname{Gs}(1+0.033 \operatorname{Cos} 360 n)\left(\operatorname{Cos} \phi \operatorname{Cos} \delta \operatorname{Sin} W s+\frac{2 \pi W_{s}}{360} \operatorname{Sin} \phi \operatorname{Sin} \delta\right)$

$$
\begin{aligned}
\text { where } & \\
\mathrm{Ho}= & \begin{array}{l}
\text { monthly mean daily extraterrestrial } \\
\text { radiation } \mathrm{KJ} / \mathrm{m}^{2}
\end{array} \\
\mathrm{Gsc}= & \begin{array}{l}
\text { solar constant }=1367 \mathrm{~W} / \mathrm{m}^{2} \\
\text { declination angle }
\end{array} \\
\phi & =\text { latitude } \\
\mathrm{Ws}= & \text { sunset hour angle for the typical day } \mathrm{n} \\
& \text { of each month in degrees } \\
& \cos ^{-1}(-\tan \phi \text { tan } \delta) \\
\mathrm{n} & =\text { mean day of each month }
\end{aligned}
$$

Equation 2 can simplified into

$$
\begin{aligned}
& \frac{H}{H_{0}}=a+b\left(T_{\max }\right) \\
& \frac{H}{H_{0}}=a+b\left(T_{\text {mean }}\right) \\
& T_{\text {mean }}=\frac{T_{(\max )}+T_{(\min )}}{2}
\end{aligned}
$$


where $\mathrm{T}_{\max }$ and $\mathrm{T}_{\text {mean }}$ are maximum temperature and mean temperature respectively. Where a and b are regression constant.

The mean temperature $\left(\mathrm{T}_{\text {mean }}\right)$ and the daily value of extraterrestrial radiation $\mathrm{H}_{0}$ were estimated using equations 3 and 6 respectively for each location and all days for the period of 1980 -1990. Clearness index $\mathrm{K}_{\mathrm{T}}$ is defined as the ratio of the observed/measured horizontal terrestrial solar radiation $(\mathrm{H})$, to the calculated/predicted horizontal extraterrestrial solar radiation $\left(\mathrm{H}_{0}\right)$.

$$
\mathrm{K}_{\mathrm{T}}=\frac{\mathrm{H}}{\mathrm{H}_{0}}
$$

The regression and correlation analyses were performed between the clearness index $\left(\mathrm{K}_{\mathrm{T}}=\mathrm{H} / \mathrm{H}_{0}\right)$ and the maximum temperature, as well as between the cleanness index and mean temperature.

Table 2 and 3 shows the values of regression coefficients(r), coefficients of determination $\left(\mathrm{R}^{2}\right)$ and regression constants ( $\mathrm{a}$ and $\mathrm{b}$ ). Figure 2 and 3 further illustrate the Angstrom page regression relationship.

Table 2: Regression and correlation parameters for $\mathbf{T}_{\max }$

\begin{tabular}{lcccc}
\hline Stations & $\mathbf{a}$ & $\mathbf{b}$ & $\mathbf{r}$ & $\mathbf{R}^{\mathbf{2}}$ \\
\hline Ikeja & -0.5324 & 0.031 & 0.923304 & 0.8525 \\
Ilorin & -0.3703 & 0.0268 & 0.938002 & 0.8798 \\
Ibadan & -0.3753 & 0.0276 & 0.860439 & 0.7404 \\
Port Harcourt & -0.5009 & 0.0303 & 0.880028 & 0.7794 \\
Benin & -0.5270 & 0.0297 & 0.927304 & 0.8599 \\
\hline
\end{tabular}

Table 3: Regression and correlation parameters for $\mathbf{T}_{\text {mean }}$

\begin{tabular}{lcccc}
\hline Stations & $\mathbf{a}$ & $\mathbf{b}$ & $\mathbf{r}$ & $\mathbf{R}^{\mathbf{2}}$ \\
Ikeja & -0.7125 & 0.0419 & 0.890894 & 0.7935 \\
Ilorin & -0.5145 & 0.0373 & 0.813575 & 0.6619 \\
Ibadan & -0.6246 & 0.0415 & 0.840220 & 0.7060 \\
Port Harcourt & -0.6223 & 0.0389 & 0.81875 & 0.6699 \\
Benin & -0.8424 & 0.04664 & 0.893401 & 0.7982 \\
\hline
\end{tabular}
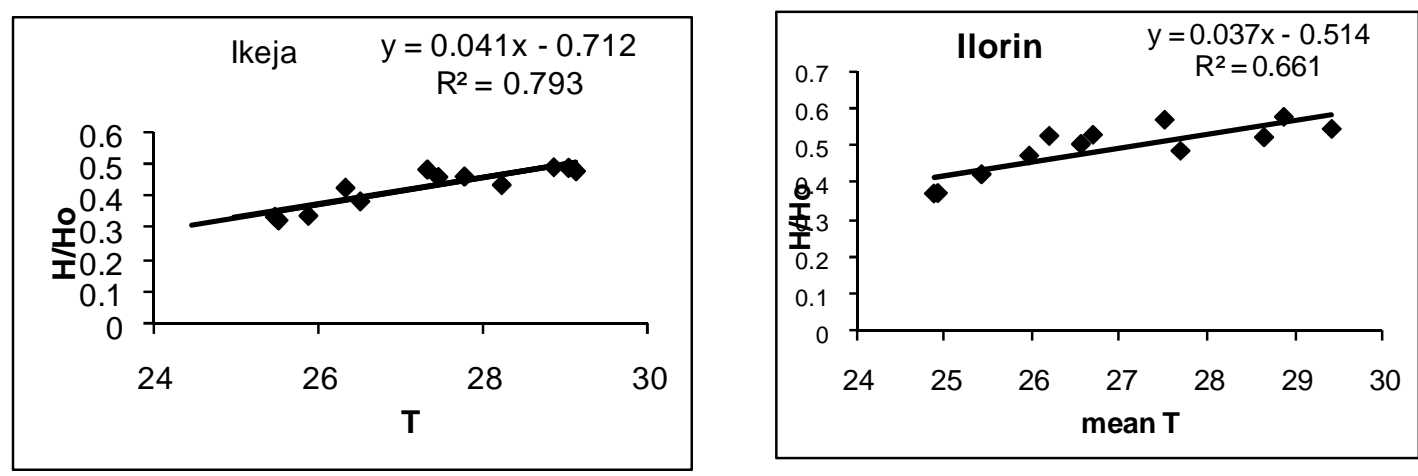

96 Journal of Science and Technology, Vol. 28, No. 2, August, 2008 

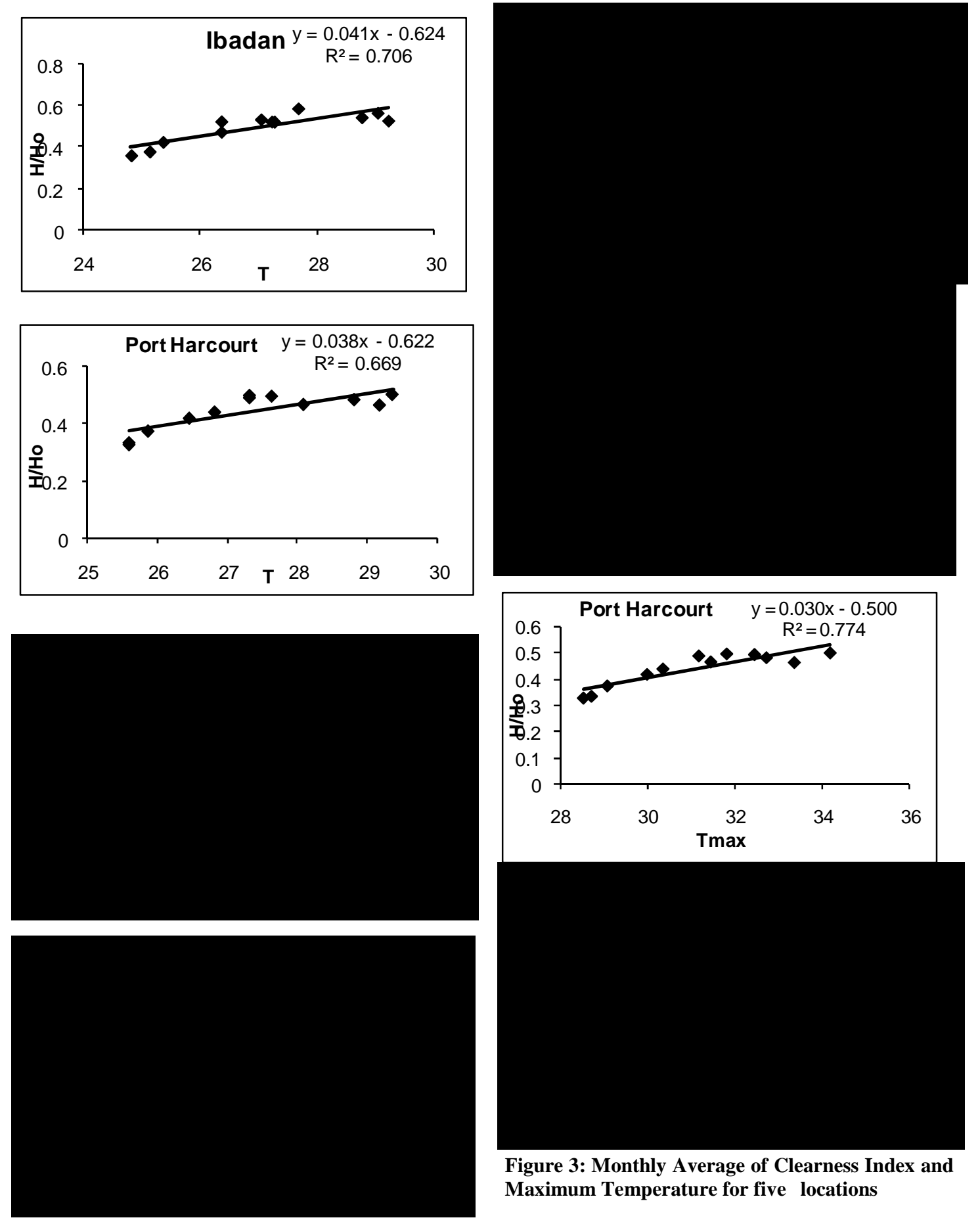

Figure 3: Monthly Average of Clearness Index and Maximum Temperature for five locations 
The monthly mean observed global solar radiation values were compared with predicted values. To assess the predictive accuracy for the monthly predicted solar radiation values, two methods were proposed by Stone (1993). The Mean Bias Error (MBE) and Root Mean Square Error were evaluated using the following equations for the five stations:

$$
\begin{aligned}
& M B E=\sum \frac{\left(H_{\text {pred }}-H_{o b s}\right)}{N} \\
& R M S E=\left[\sum\left(\frac{\left(H_{\text {pred }}-H_{o b s}\right)^{2}}{N}\right)\right]^{1 / 2}
\end{aligned}
$$

$\mathrm{H}_{\text {pred }}$ is the predicted value from the model. $\mathrm{H}_{\mathrm{obs}}$ is the measured or observed value and $\mathrm{N}$ is the total number of observation. The test of RMSE provides information on the short-term performance of studied model as it allows a term by term comparison of the actual deviation between the calculated value and the measured value. Table 3 presents the RMSE and MBE for the 5 locations. Igbai (1993) and Halouani et al (1993) recommended that a zero value of RMSE is ideal while a low MBE is desirable.

\section{RESULTS AND DISCUSSION}

Tables 2 and 3 contains summaries of the results obtained from the application of equation (4) and (6) to the monthly mean global solar radiation values for the 5 stations under study. From table 2 and 3, it is clear that the regression coefficients ( $\mathrm{a}$ and $\mathrm{b}$ ), correlation coefficients $\mathrm{r}$ and coefficients of determination $\mathrm{R}^{2}$ vary from one place to another.

Considering clearness index-maximum temperature, the correlation coefficients $(0.86-0.93)$ are high for all the stations. This implies that, there is statistically significant relationship between the clearness index and the maximum temperature. This is further demonstrated by high values of coefficient of determination $\mathrm{R}^{2}(0.74-$ 0.87 ) across the stations.
The clearness index-mean temperature correlation coefficient (0.81-0.89) is also high for the stations and there are high values of coefficients of determination (0.66-0.79) across the stations.

\section{Mean Temperature}

For Ikeja, the coefficient of determination of 0.7937 implies $79.37 \%$ of clearness index can be accounted for by mean temperature using Angstrom model equation.

$\frac{\mathrm{H}}{\mathrm{H}_{0}}=-0.7125+0.04190\left(\mathrm{~T}_{\text {mean }}\right)$

Correlation coefficient of 0.8909 exist between the clearness index and $\mathrm{T}_{\text {mean }}$

For Ilorin, the coefficient of determination of 0.6619 implies $66.19 \%$ of clearness index can be accounted for by mean temperature using Angstrom model equation.

$$
\frac{\mathrm{H}}{\mathrm{H}_{0}}=-0.5145+0.0373\left(\mathrm{~T}_{\text {mean }}\right)
$$

Correlation coefficient of 0.8136 exists between the clearness index and mean temperature.

For Ibadan, the coefficient of determination of 0.7060 implies $70.60 \%$ of clearness index can be accounted for by the mean temperature which can be expressed as:

$$
\frac{\mathrm{H}}{\mathrm{H}_{0}}=-0.6226+0.0329\left(\mathrm{~T}_{\text {mean }}\right)
$$

Correlation coefficient of 0.8402 exists between the clearness index and mean temperature.

For Port Harcourt, the coefficient of determination of 0.6699 implies $66.99 \%$ of clearness index can be accounted for by the mean temperature, which can be expressed as,

$$
\frac{\mathrm{H}}{\mathrm{H}_{0}}=-0.6223+0.0389\left(\mathrm{~T}_{\text {mean }}\right)
$$


Correlation coefficient of 0.8188 exists between the clearness index and mean temperature.

For Benin, the coefficient of determination of 0.7798 implies $77.98 \%$ of clearness index, which can be expressed as

$$
\frac{\mathrm{H}}{\mathrm{H}_{0}}=-0.8424+0.04664\left(\mathrm{~T}_{\text {mean }}\right)
$$

Correlation coefficient of 0.8934 exists between the clearness index and mean temperature.

\section{Maximum Temperature}

In Ikeja, the coefficient of determination of 0.8525 implies $85.25 \%$ of clearness index can be accounted for by maximum temperature using Angstrom model equation.

$$
\frac{\mathrm{H}}{\mathrm{H}_{0}}=-0.5324+0.031\left(\mathrm{~T}_{\max }\right)
$$

Correlation coefficient of 0.9233 exists between the clearness index and maximum temperature.

For Ilorin, the coefficient of determination of 0.8798 implies $87.98 \%$ of clearness index can be accounted for by maximum temperature using Angstrom model equation.

$\frac{\mathrm{H}}{\mathrm{H}_{0}}=-0.3703+0.0268\left(\mathrm{~T}_{\max }\right)$

Correlation coefficient of 0.9380 exists between the clearness index and maximum temperature.

For Ibadan, the coefficient of determination of 0.7404 implies $74.04 \%$ of clearness index can be accounted for by maximum temperature using Angstrom model equation.

$$
\frac{\mathrm{H}}{\mathrm{H}_{0}}=-0.37534+0.0276\left(\mathrm{~T}_{\max }\right)
$$

Correlation coefficient of 0.8604 exists between the clearness index and maximum temperature.

For Port Harcourt, the coefficient of determination of 0.744 implies $74.4 \%$ of clearness index can be accounted for by maximum temperature using Angstrom model equation.

Correlation coefficient of 0.8800 exists between the clearness index and maximum temperature.

$$
\frac{\mathrm{H}}{\mathrm{H}_{0}}=-0.5009+0.03030\left(\mathrm{~T}_{\max }\right)
$$

For Benin, the coefficient of determination of 0.8599 implies $85.99 \%$ of clearness index can be accounted for by maximum temperature using Angstrom model equation.

Correlation coefficient of 0.9273 exists between the clearness index and maximum temperature.

$\frac{\mathrm{H}}{\mathrm{H}_{0}}=-0.52270+0.0297\left(\mathrm{~T}_{\max }\right)$

The regression coefficients obtained in this work indicate good performance, with earlier result reported by Iheonu (2001). The low values of the Mean Bias Error and Root Means square Error as evidences on Table 4 and Table 5 are quite remarkable.

Table 4: statistical performance of proposed model for maximum temperature

\begin{tabular}{lcc}
\hline Stations & MBE & RMSE \\
\hline Ikeja & $-8.643 \times 10^{-4}$ & 0.023468 \\
Ilorin & $-8.330 \times 10^{-8}$ & 0.023995 \\
Ibadan & $1.393 \times 10^{-3}$ & 0.036014 \\
Port Harcourt & $1.608 \times 10^{-5}$ & 0.028941 \\
Benin & $8.330 \times 10^{-8}$ & 0.024950 \\
\hline
\end{tabular}

The results show that the Angstrom - page model is effective and useful in predicting global solar radiation in tropical Nigeria. 
Table 5: statistical performance of proposed model for mean temperature

\begin{tabular}{lrl}
\hline Locations & \multicolumn{1}{c}{ MBE } & RMSE \\
\hline Ikeja & $2.283 \times 10^{-3}$ & 0.027754 \\
Ilorin & $7.257 \times 10^{-4}$ & 0.029954 \\
Ibadan & $8.330 \times 10^{-8}$ & 0.038370 \\
Port Harcourt & $-5.000 \times 10^{-6}$ & 0.035805 \\
Benin & $-8.333 \times 10^{-10}$ & 0.035012 \\
\hline
\end{tabular}

\section{SUMMARY OF THE RESULTS}

The Angstrom - Page linear regression model has been applied to estimates global solar irradiance from maximum and mean temperature data at five tropical stations. The equations of the models together with their coefficients of determination are summarised in the Table below:

Table 6: Summary of the global solar irradiance and mean temperature

\begin{tabular}{lcc}
\hline Stations & $\mathrm{K}_{\mathrm{T}}$ & $\mathrm{R}^{2}$ \\
\hline Ikeja & $-0.7125+0.0419\left(\mathrm{~T}_{\text {mean }}\right)$ & 0.7937 \\
Ilorin & $-0.5145+0.0373\left(\mathrm{~T}_{\text {mean }}\right)$ & 0.6619 \\
Ibadan & $-0.6226+0.0329\left(\mathrm{~T}_{\text {mean }}\right)$ & 0.7060 \\
Port Harcourt & $-0.6223+0.0389\left(\mathrm{~T}_{\text {mean }}\right)$ & 0.6699 \\
Benin & $-0.8424+0.04664\left(\mathrm{~T}_{\text {mean }}\right)$ & 0.7798 \\
\hline
\end{tabular}

Table7: Summary of the global solar irradiance and maximum temperature

\begin{tabular}{lcc}
\hline Stations & $\mathrm{K}_{\mathrm{T}}$ & $\mathrm{R}^{2}$ \\
\hline Ikeja & $-0.5324+0.0310\left(\mathrm{~T}_{\max }\right)$ & 0.8525 \\
Ilorin & $-0.3703+0.0268\left(\mathrm{~T}_{\max }\right)$ & 0.8798 \\
Ibadan & $-0.6226+0.0276\left(\mathrm{~T}_{\max }\right)$ & 0.7404 \\
Port Harcourt & $-0.6223+0.0303\left(\mathrm{~T}_{\max }\right)$ & 0.7794 \\
Benin & $-0.8424+0.0297\left(\mathrm{~T}_{\max }\right)$ & 0.8599 \\
\hline
\end{tabular}

\section{CONCLUSION}

The Angstrom-page coefficient fitting using daily global radiation and Temperature for Nigerian, showed very good result. The tests of performance of the model for the five stations have been done in terms of the widely used statistical indicators, Mean Bias Error (MBE) and Root Mean Square Error (RMSE). It was found from statistical model performance indicators that the models provided reasonably high degree of precision in the prediction of average monthly global solar radiation on horizontal surfaces. Our result indicates that the regression obtained in this paper may be used satisfactorily for the estimation of global radiation in Tropical station in Africa.

\section{ACKNOWLEDGEMENT}

The authors wish to acknowledge the management of the Nigeria Meteorological Agency, Oshodi, Lagos State, for making the data of global solar radiation of surface temperature available.

\section{REFERENCES}

Akinbode, F.O. (1992). Solar Radiation in Minna; Correlation with Meteorological Data. Nigeria Journal of Renewable Energy, 3: 9-17.

Angstrom, A. (1924). Solar and terrestrial radiation. Meteorological Society, 50: 121-125.

Arinze, E. A and Obi, S. E. (1983). Solar Energy Availability at prediction in Northern Nigeria. Nigeria Journal of Solar Energy, 3: 3-10.

De Jons, R. and Stewart, D.W. (1993). Estimating global radiation from common Meteorological variables in Western Canada. Canada Journal, 73: 509-518.

Fagbenle, R. O. (1990). Estimation of Total Solar Radiation in Nigeria using Meteorological data. Nigeria Journal of Renewable Energy, 1: $1-10$.

Folayan, C.O. (1988). Estimation On Global Solar Radiation Bound for some Nigeria Cities. Nigeria Journal of Solar Energy, 3: 3-10.

Halouani, M., Nguyen, C. T and Vo. Ngoc, D. (1993). Calculation of Monthly Average Global Solar Radiation on Horizontal Surface Using Daily Hour of Bright Sunshine. Solar Energy, 50: 247-258. 
Hargreaves, G.L., Hargreaves, G.H. and Riley, P. (1985). Irrigation Water requirements on the Senegal River Basin. Journal Irrigation and Drainage Engineering. ASCE III, 265275.

Igbai, M. (2001). An Introduction to Solar Radiation, Academic press. New York, 59-67.

Iheonu, E.E. (2001). Model for the prediction of Average Monthly Global Solar Radiation in horizontal surface for some location in the tropics, Using Temperature Data. Nigeria Journal of Renewable Energy, 9: 12-15.

Page, J.K. (1964). The estimation of monthly mean values of daily total shine wave radiation on vertical of inclined surface from sunshine records, for latitude $40^{0} \mathrm{~N}-40^{\circ} \mathrm{S}$. Proceedings of UN New Sources Energy, 4: 378.
Rietveld, M.R. (1978). A new method for estimating the regression coefficient formula relating solar radiation to sunshine. Agric Meteorology 19: 43-252.

Soler, A. (1978). Statistical Comparison for 77 European Stations of 7 Sunshine Based Models. Solar Energy, 45:365-370.

Stone, R.J. (1993). Improved Statistical Procedure for the Evaluation of Solar Radiation Estimation Models. Solar Energy, 51: 289290. 